\title{
Private Shareholding: An Analysis of an Eclectic Group of Central Banks
}

\author{
Jannie Rossouw \\ School of Economics and Business Sciences, University of the Witwatersrand
}

Accepted: October 2015

\begin{abstract}
Although the title seems to be a contradictio in terminis, this paper identifies a small, eclectic number of central banks with private shareholders about which little has been published. It is shown that only the central banks of Belgium, Greece, Italy, Japan, South Africa, Switzerland, Turkey and the United States (US) Federal Reserve Banks allow shareholding other than by the government of the respective countries, although not in all instances by the general public. This paper considers private shareholding in this eclectic group of central banks, despite the trend of nationalising central banks that commenced in 1935. Private shareholding is defined as shareholding in a central bank by any party other than the respective government or governments (e.g. the European Central Bank) where the central bank is located.

Large differences in the classes of shareholders of these eclectic central banks and differences in their approaches to dividend payments are highlighted in the paper. The conclusions reached are, firstly, that investment only in the shares of the central banks of Belgium and Greece (albeit only for residents in the latter instance) can be regarded as growth investments. Secondly, shareholding in the Italian central bank has been used to recapitalise ailing commercial banks. Thirdly, shareholders play no role in the formulation and implementation of monetary policy. Lastly, the shareholding structure of these banks contributes to improved governance in the case of the central banks of Belgium, Greece, Italy, South Africa, Switzerland and Turkey, but no evidence can be found that central banks with shareholders in any way outperform central banks without shareholders.
\end{abstract}

Key words: central banks, shareholders

JEL: E42, 50, 58, 59

\section{$1 \quad$ Introduction}

The title of this paper seems to be somewhat of a contradictio in terminis, as it gives rise to the question whether there are indeed central banks with private shareholders. Private shareholding is defined as shareholding in a central bank by any party other than the respective government or governments (e.g. the European Central Bank) where the central bank is located.

This paper reviews this eclectic group of central banks about which surprisingly little has been published. The first challenge is the identification of these central banks, as there is no "generally accepted" or standardised list of such central banks, and very little has been published that identifies or compares these central banks.

A review of the available literature shows considerable divergence between these institutions. Central banks with private shareholders identified from the available literature were approached with a request to complete questionnaires on their shareholding structures. This paper reports, among others, the information obtained from these questionnaires. It further considers the degree to which private shareholding in the remaining central banks plays a role in their structures and operations.

The policy conduct of central banks, comparisons of such conduct, and policy options of central banks receive considerable attention in the literature on central banking and monetary policy. However, little has been published on the institutional structures of central banks. This paper seeks to make a contribution to a specific aspect of this under-researched area of central banking.

The remainder of the paper is organised as follows: Section 2 reviews the literature on central banks with private shareholding. Section 3 describes the salient features of a questionnaire on the 
shareholding of central banks. Section 4 compares central banks having private shareholding and reports the survey results received from the central banks, as well as other salient features of these institutions. The conclusions follow in Section 5.

\section{Literature review $^{1}$}

The available literature shows that the ownership structure of central banks has been the subject of considerable change over time. Recent literature on this topic is limited to two papers by Rossouw and Breytenbach (Rossouw \& Breytenbach, 2011a; Rossouw \& Breytenbach 2011b), while various editions of the book, Central Banking, by De Kock (see, for instance, De Kock, 1939; De Kock, 1956; or De Kock, 1974) also cover these institutions. De Kock served as Deputy Governor (from 1932 to 1945) and as Governor (from 1945 to 1962) of the South African Reserve Bank (Meiring, 1994). Central Banking, first published in 1939, was regarded as one of the first comprehensive textbooks on this topic and was translated into Spanish, Portuguese, Japanese, Hindi and Gujarati.

At the time, De Kock (1939:298) classified the ownership of the capital of central banks into seven different groups:

1) All shares held by the government.

2) All shares held by private shareholders (juristic persons and the general public).

3) All shares held by banks.

4) Shares held by the government and private shareholders.

5) Shares held by the government and banks.

6) Shares held by the government, banks and private shareholders.

7) All shares held by banks and private shareholders.

This paper focuses on central banks with shareholding in any combinations of 2 to 7 above. In the case where commercial banks are not specifically identified in 2 to 7 above (i.e. 2 and 4), this does not imply a prohibition on such shareholding, but merely indicates that banks are not under any obligation to hold shares in the central bank. De Kock (1939:299) states in respect of 2 and 4 above that "banks may be found amongst the shareholders of some of these central banks, but not because they were originally required to subscribe to the capital of the central bank". In the case of $3,5,6$ and 7, banks have an obligation to hold shares in the central bank as a requirement of their licensing conditions.

De Kock (1939:298) identified the central banks in Australia, Bulgaria, China, Costa Rica, Finland, Latvia, Russia, Sweden and Uruguay as institutions where all shares were held by the government by 1935 (i.e. as being in Group 1 above). Sole ownership by the government was therefore the exception at the time, rather than the rule, as is currently the case, as central banks ${ }^{2}$ were to be found in 40 countries by 1935 .

The remaining central banks had any combinations of shareholder structures described in 2 to 7 above (see Rossouw \& Breytenbach, 2011a:S125 for details of these institutions). This group of central banks includes the 12 Federal Reserve Banks in the United States (US) as one institution. Some of the central banks in existence by 1935 ceased to exist or were replaced by other institutions, for example the Reichsbank of Germany was replaced by the Bundesbank, while the central banking functions of the Commonwealth Bank of Australia were taken over by the Reserve Bank of Australia in 1950.

The ownership structures of central banks started changing from 1935. The first nationalisation of a central bank can be a topic of debate. Rossouw and Breytenbach (2011a:S125 \& 2011b:85) state that the Reserve Bank of New Zealand was nationalised in 1935. This nationalisation is confirmed by the Reserve Bank of New Zealand (2009). Nationalisation was part of an approach of "big government" in the aftermath of the Great Depression in New Zealand, when the state accepted responsibility for a wide range of functions in the economy (Reserve Bank of New Zealand, 2009). 
To the contrary, De Kock (1956) identifies Denmark as the first country where a central bank was nationalised, stating that this happened in 1936. The objective of nationalisation of this central bank was to give the Danish Parliament and government greater insight into the policies and activities of the central bank. Naturally, nationalisation is not a precondition for greater insight; this objective can be achieved in a number of different ways. Examples of ways in which this objective can be realised, irrespective of the ownership structure of the central bank, include a requirement that the Governor of a central bank appears periodically before a standing or select committee of Parliament and/or a requirement that the annual report of the central bank is tabled in Parliament for debate. The first nationalisation of a central bank and the reasons for nationalisation therefore remain debating points.

As shown below, De Kock was somewhat of a visionary in 1939 when stating that " ... a definite trend in the direction of greater state intervention in the ownership and administration of central banks is to be observed in recent changes in central bank statutes ..." (De Kock, 1939:324). De Kock (1939:324) adds that the League of Nations stated on page 81 of its Monetary Review for the period 1937 to 1938 that "(i)n the statutes as drawn up or amended in recent years, the State has generally assumed a more important role both in respect of the ownership and management of central banks".

In De Kock's assessment, “( $\mathrm{t}$ )his trend towards increased State intervention ... commenced in 1930 under the stress of the world-wide depression ... and was accentuated by the suspension of the gold standard ..." (De Kock, 1939:325). De Kock adds that "(i)n many cases central banks were virtually obliged to provide the financial facilities demanded by the State ... " (1939:325).

After the Second World War, nationalisation of central banks gained momentum (De Kock, 1956:319), and, with the exception of the Central Bank of Pakistan ${ }^{3}$, all central banks established after the War had no shareholders other than the government since their inception (De Kock, 1956:319). By 1974, 27 central banks had some form of private shareholding (De Kock, 1974:305) in terms of the definitions in 2 to 7 above. At that time, the central banks of Greece, Italy, South Africa, Switzerland and the 12 Federal Reserve Banks in the US had no shareholding by their respective governments. In Chile, Colombia, Ecuador, Portugal and Turkey, the respective governments held a minority shareholding (De Kock, 1974:305). In Austria, Belgium, Japan, Mexico, Pakistan and Venezuela, the respective governments held at least 50 per cent of the share capital (De Kock, 1974:305).

De Kock (1974:306 and 307) draws attention to the imminent nationalisation of the central bank of Colombia, but the central banks of Chile, Ecuador, Portugal, Mexico, Pakistan and Venezuela were also nationalised in 1974 and 1975. No information in English could be obtained further elucidating these nationalisations, but the nationalisation of the central bank of Portugal might be linked to a change in government in that country that resulted, inter alia, in the independence of its territories abroad (e.g. Angola and Mozambique). Reasons for this "wave" of central-bank nationalisation, particularly in South America, could be an area of further research on this topic.

Rossouw (2004) stated incorrectly that "the Reserve Bank ... [in South Africa] ... the Belgium National Bank and the Swiss National Bank are the only central banks left with the public as shareholders" by 2004. Lybek and Morris (2004:7) also incorrectly identified the central banks of Austria, Belgium, Greece, Italy, Japan, Pakistan, South Africa, Switzerland and the Federal Reserve Banks in the US as institutions with private shareholders, as the Turkish central bank also has shareholders and the central bank of Pakistan was nationalised in 1975.

By 2004, central banks with private shareholders were therefore to be found in Austria, Belgium, Greece, Italy, Japan, South Africa, Switzerland and Turkey, while the 12 Federal Reserve Banks in the US also had shareholders at that time.

This changed in 2010, when the central bank in Austria was nationalised. This nationalisation received very little attention at the time, perhaps because no shares were held by the general public. Only the Austrian government (with 70.27 per cent of the share capital) and Austrian banks 
held shares in the Austrian National Bank before its nationalisation. The objectives of the nationalisation were to: (i) improve government supervision over the central bank; and (ii) avoid possible conflicts of interest, as banks supervised by the Austrian National Bank were also its shareholders and appointed its governing board (EN Publishing, [s.a.]).

Remaining central banks with private shareholders are therefore those in Belgium, Greece, Italy, Japan, South Africa, Switzerland and Turkey, and the 12 Federal Reserve Banks in the US. Archer and Moser-Boehm (2013) concur with this list of central banks.

\section{Questionmaire on shareholding of central banks}

In the literature, little has been published on the organisational and governance structures of central banks, and even less has been written about central banks with shareholders. The following summary shows that there are considerable differences in shareholding among this eclectic group of central banks, ranging from:

1) government shareholding combined with institutional shareholding;

2) only commercial banks being shareholders, with shareholding banks obliged to hold such shares;

3) commercial banks obliged to hold central-bank shares, combined with shareholding by private individuals, to

4) private shareholding only (which can include institutions such as commercial banks and private individuals), but with no obligation on any party to hold such shares.

Likewise, the research shows that the rights of the shareholders in these institutions can differ considerably, while institutional dividend policies and practices also show considerable differences. Particular differences are as follows:

5) Conditions of private shareholding differ, e.g. there may be any number of possible combinations of government and/or private shareholding, where the latter may be limited to commercial banks (with or without a legal obligation to hold such shares), or may include any business enterprise and/or private individuals.

6) Eligibility for shareholding differs, e.g. instances where only institutions and/or individuals domiciled in and/or citizens of the country where the central bank is located are eligible for shareholding.

7) Powers of shareholders differ, e.g. in respect of voting (if applicable) attached to shares and/or preconditions for exercising voting rights.

In an effort to overcome these difficulties and to foster a common understanding of private shareholding in central banks, a questionnaire was compiled and distributed to the company secretaries of the central banks of Belgium, Greece, Italy, Japan, South Africa, Switzerland and Turkey. In the case of the US, copies of the questionnaire were distributed to the Secretary of the Board of Governors of the Federal Reserve System in Washington (the Fed) and to the Federal Reserve Bank of Atlanta.

Responses were received from the central banks in Italy, Switzerland and Turkey. In the case of the South African Reserve Bank, the questionnaire was completed by Rossouw, author of his paper and one of the authors of Rossouw and Breytenbach (2011a; 2011b), who served as Secretary of the Bank on two occasions (from 1994 to 2000 and from 2010 to 2011). This was supplemented by research on all central banks with shareholders. The findings are analysed in the next section.

\section{Comparison of central banks with private shareholders}

This section analyses the salient features of the central banks identified above. However, the 12 Federal Reserve Banks in the US deserve special mention, as is explained below. The central banks with shareholders can be classified as follows in terms of the classification by De Kock (1939:298) highlighted above: 
8) All shares held by private shareholders (juristic persons and the general public, which can include banks, but with no obligation on banks to hold such shares): Greece and South Africa.

9) All shares held by banks: Italy and the 12 Federal Reserve Banks.

10) Shares held by the government and private shareholders (which can include banks, but with no obligation on banks to hold such shares): Belgium and Japan.

11) Shares held by the government and banks: No examples.

12) Shares held by the government, banks and private shareholders: Turkey and Switzerland (cantonal governments, rather than central government).

13) All shares held by banks (with an obligation to hold such shares) and private shareholders: No examples.

One central theme that emerges from the analysis of the questionnaires and the information available on the central banks with private shareholders is that their shareholders play no role in the formulation and implementation of monetary policy (see, also, Archer \& Moser-Boehm, 2013:7 on this matter).

\subsection{Federal Reserve Bank in the United States}

The 12 Federal Reserve Banks in the US form part of the Federal Reserve System ("the Fed"). The 12 Federal Reserve Banks have commercial banks in their Federal Reserve districts as shareholders. No questionnaires were received from the Fed or from the Federal Reserve Bank. The analysis in this section is therefore based on available literature.

In the establishment of the Fed in 1913, particular care was taken to avoid some of the perceived shortcomings that contributed to opposition to the renewal of the charters of the two earlier central banks in the US, the First Bank of the United States (which existed from 1791 to 1811) and the Second Bank of the United States (which operated from 1816 to 1836).

The Federal Reserve Act provides for a Board of Governors as a federal-government agency which has, inter alia, broad oversight responsibility for the operations and activities of the 12 Federal Reserve Banks. Section 5.1 of the Federal Reserve Act stipulates:

“(t)he capital stock of each Federal Reserve Bank shall be divided into shares of $\$ 100$ each. The outstanding capital stock shall be increased from time to time as member banks increase their capital stock and surplus or as additional banks become members, and may be decreased as member banks reduce their capital stock or surplus or cease to be members. Shares of the capital stock of Federal Reserve Banks owned by member banks shall not be transferred or hypothecated (Federal Reserve Act; see, also, The Federal Reserve System, 2005)."

Section 7.1(A) of the Federal Reserve Act stipulates that stockholders (own emphasis) of the Federal Reserve Banks are entitled to an annual dividend of 6 per cent on the paid-in capital stock (own emphasis) that they hold in Federal Reserve Banks (see also, The Federal Reserve System, 2005). This leaves the impression that the interests of member banks in the Federal Reserve Banks show many elements of bondholding, rather than shareholding. The 12 Federal Reserve Banks are therefore not included in the further analysis in this paper.

\subsection{Salient features of other central banks}

The rest of the central banks with private shareholders identified above have shareholders in the conventional sense of the word, but the research shows that the rights of the shareholders in these institutions can differ considerably, and, also, that institutional dividend policies and practices differ considerably.

\subsubsection{Belgium}

The Belgian central bank (official English name: "National Bank of Belgium") has an issued share capital amounting to $€ 10$ million, represented by 400000 shares (each with a nominal value of $€ 25)$. The Belgian state holds 50 per cent of these shares, while the remaining shares are listed on 
the NYSE Euronext and are held by companies and private individuals. The price was $€ 3099.45$ per share at the end of August 2015. Each share confers the right to one vote at the general meeting of shareholders and the statue of the bank does not limit shareholding or voting in any way.

The bank annually pays shareholders a first dividend of 6 per cent of the share capital (amounting to $€ 1.5$ per share on the nominal value of $€ 25$ per share) and a second dividend calculated as 50 per cent of the net proceeds from the portfolio of assets which the bank holds as counterpart to its total reserves, after deduction of corporate tax. In 2015 total dividends (paid on 22 May 2015) amounted to $€ 108.69$ per share after withholding tax. The current dividend yield is 3.5 per cent.

\subsubsection{Greece}

The Greek central bank (official English name: "Bank of Greece") has an issued share capital amounting to $€ 111243362.00$, represented by 19864886 shares. The nominal value of each share is $€ 5.60$. By law, the Greek government and public enterprises may not hold more than 35 per cent of the nominal issued share capital of the bank. Shares are held by companies and private individuals.

Every shareholder who owns at least 75 shares and has been registered as a shareholder for not less than three months prior to the general meeting of shareholders can vote at the meeting, on condition that the shareholder has Greek citizenship or is a company registered in Greece, which is also a condition for shareholding.

The bank pays an annual first dividend equal to 12 per cent of the nominal value of the shares, amounting to $€ 0.67$ per share per annum, should profits permit. A supplementary second dividend is determined annually by the General Council (Board) of the bank, which is dependent on the profitability of the bank. Total dividends per share amounted to only $€ 0.49728$ per share before withholding tax of 10 per cent in 2014. This implies that the bank could not even afford to pay the first dividend of $€ 0.67$ that year.

The shares trade on the Athens Exchange and the share price was about $€ 8.96$ at the end of August 2015. This is a substantial decline from its level of $€ 30.67$ at the beginning of 2011 . The current dividend yield is 5.6 per cent before withholding tax.

\subsubsection{Italy}

The Italian central bank (official English name: "Bank of Italy") previously had an issued share capital amounting to $€ 156000$, represented by 300000 shares. The nominal value of each share was $€ 0.52$. This changed in 2014 , when the capital of the bank was revalued to $€ 7.5$ billion, which is a more accurate reflection of the underlying value of the capital and reserves of the bank (Investor Active, 2014). This revaluation resulted in an improvement of the capital position of Italian banks holding shares in the central bank.

The main financial beneficiaries of the revaluation were the two banks with the largest shareholding in the central bank, namely Intesa Sanpaolo and UniCredit CRD.MI (Investor Active, 2014). From an overall perspective, however, the main beneficiaries were Banca Monte dei Paschi Siena ${ }^{4}$ and Banca Carige, two banks with a shareholding in the central bank experiencing financial difficulties at the time that could report an increase in their asset holdings owing to the revaluation ${ }^{5}$ (Investor Active, 2014). This improved their liquidity and solvency positions.

The ownership of the shares is governed by law and the shares may be transferred only with the prior consent of the Board of Directors. All shares are held by Italian banks and similar financial institutions, and the bank has no other companies or private individuals as shareholders.

Shareholders who have held 100 or more shares for at least three months before a meeting of shareholders have the right to attend shareholders' meetings. Shareholders entitled to attend have one vote for every 100 shares held up to 500 shares, and one vote for every 500 shares held over and above the first 500, but voting per shareholder, irrespective of the number of shares held, is limited to a maximum of 50 votes. 
The bank pays an annual first dividend equal to 6 per cent of the nominal value of the shares, which amounts to €9 360 per annum, a second dividend of 4 per cent per annum of the nominal value of the shares, amounting to $€ 6240$ per annum, and a third "supplementary" annual dividend not exceeding 4 per cent of the amount of the reserves. The shares do not trade freely. No current or latest price or dividend yield can therefore be determined.

\subsubsection{Japan}

The Japanese central bank (official English name: "Bank of Japan") has an issued share capital amounting to $¥ 100$ million, represented by 1 million shares. The nominal value of each share is $¥ 100$. The government owns 55 per cent of the shares. The shares trade on the JASDAQ Securities Exchange. Companies and private individuals may hold shares in the bank. The bank does not hold an annual general meeting of shareholders.

The bank pays an annual dividend not exceeding 5 per cent of the nominal issue value of the shares, amounting to $¥ 5$ per share per annum. This dividend is prescribed by legislation. At a price of $¥ 48000$ per share at the end of August 2015, the effective yield is 0.01 per cent per annum. This yield should be viewed against very low yields on fixed-interest financial instruments currently prevailing in Japan, as well as periods of deflation in that country.

\subsubsection{South Africa}

The South African central bank (official English name: "South African Reserve Bank") has an issued share capital amounting to R2 million, represented by 2 million shares. The nominal value of each share is R1.00. The South African government holds no shares in the bank, but can buy shares within the legal prescriptions (e.g. up to a maximum of 10000 shares) should it wish to do so. The shares trade on an over-the-counter market and the price was R1.55 per share at the end of August 2015. Companies (including banks) and private individuals may hold shares in the bank.

Every shareholder who owns at least 200 shares and has been registered as a shareholder for not less than six months prior to the ordinary general meeting of shareholders can vote at the meeting, on condition that the shareholder is ordinarily resident in South Africa. No shareholder may hold more than 10000 shares in the bank. Shareholders have one vote for every 50 shares, with a maximum of 200 votes. The voting rights of company groups with board or ownership control, and of family groups, are limited to 200 votes, irrespective of the number of shares they hold over 10000 .

The bank pays an annual dividend of not more than 10 per cent of the nominal value of the shares, amounting to R0.10 per share per annum. This dividend is prescribed by legislation and is subject to dividend withholding tax of 15 per cent (hence a net dividend of 8.5 cents per annum). At the prevailing share price, the dividend amounted to a return of 6.5 per cent per annum before dividend withholding tax.

\subsubsection{Switzerland}

The Swiss central bank (official English name: "Swiss National Bank") has an issued share capital amounting to $\mathrm{CH} f 25$ million, represented by 100000 shares with a nominal value of $\mathrm{CH} f 250$ each. About 52 per cent of the shares are owned by cantons and cantonal banks. The remaining shares are mostly owned by other companies and private individuals. The confederate government does not hold any shares. Registration with voting rights is limited to 100 shares per shareholder. This limitation does not apply to Swiss public-law corporations and institutions or to cantonal banks pursuant to section 3a of the Federal Banking Act of 8 November 1934.

The annual dividend may not exceed 6 per cent of the nominal value of the share capital. The shares trade on the SIX Swiss Exchange and the price was $\mathrm{CH} f 1117$ per share at the end of August 2015. The effective yield was therefore 1.3 per cent per annum, which should be viewed against the backdrop of prevailing low yields on fixed-interest instruments in Switzerland.

The bank convenes an annual general meeting of shareholders, and any shareholder listed in the share register is eligible to attend the meeting. 


\subsubsection{Turkey}

The Turkish central bank (official English name: "Central Bank of the Republic of Turkey") has an issued share capital amounting to TL25 000, represented by 250000 shares. The shares have a nominal value of TL0.012 each. The bank has four classes of shares. Class A shares are held exclusively by the Turkish Treasury and represent 51 per cent of the capital. Class B shares are held by national banks operating in Turkey. A maximum of 15000 shares can be held as class $\mathrm{C}$ shares by banks other than national banks holding shares as Class B shareholders. Class D shares are held by Turkish commercial institutions and companies, and private individuals of Turkish nationality. Shareholding is therefore limited to Turkish citizens and entities. At the bank's annual general meeting of shareholders, shareholders have one vote for every 10 shares held.

The bank pays an annual first dividend of 6 per cent of the nominal value of its share capital to shareholders, and a second dividend not exceeding 6 per cent per annum of the nominal value of the share capital can also be paid to shareholders, subject to annual approval by the General Assembly (general meeting of shareholders) of the central bank. As a result, the maximum annual profit distribution to shareholders is limited to 12 per cent of the nominal value of share capital. This amounts to TL0.12 per share per annum.

The shares in the Turkish central bank cannot be transferred freely between shareholders. A dividend yield for the share can therefore not be calculated.

Table 1 below summarises the salient features of the central banks discussed in this section, with the exception of the 12 Federal Reserve Banks, as the shareholding of commercial banks in these banks comprises a reserve holding, rather than a shareholding in the true sense of the word as is the case with other central banks discussed in the section. The analysis and the summary in Table 1 clearly show that shareholding in central banks has different meanings in different jurisdictions. In particular, there are considerable differences in the dividend policies of these central banks.

Table 1

Summary of the salient features of central banks with shareholders

\begin{tabular}{|c|c|c|c|c|c|c|c|}
\hline & Belgium & Greece & Italy & Japan & South Africa & Switzerland & Turkey \\
\hline $\begin{array}{l}\text { Official } \\
\text { government } \\
\text { shareholding }\end{array}$ & Yes & No & No & Yes & No & Yes $^{*}$ & Yes \\
\hline $\begin{array}{l}\text { Official } \\
\text { shareholding } \\
\text { by banks }\end{array}$ & No & No & Yes & No & No & Yes & Yes \\
\hline $\begin{array}{l}\text { General } \\
\text { shareholding }\end{array}$ & Yes & Yes & No & Yes & Yes & Yes & Yes \\
\hline $\begin{array}{l}\text { General } \\
\text { ownership } \\
\text { limitations (e.g. } \\
\text { citizens only) }^{\star \star}\end{array}$ & No & Yes & Yes & No & No & No & Yes \\
\hline $\begin{array}{l}\text { Annual meeting } \\
\text { of shareholders }\end{array}$ & Yes & Yes & Yes & No & Yes & Yes & Yes \\
\hline $\begin{array}{l}\text { Voting } \\
\text { limitations }\end{array}$ & Yes & Yes & Yes & $\mathrm{N} / \mathrm{A}$ & Yes & Yes & Yes \\
\hline $\begin{array}{l}\text { Dividend } \\
\text { payment (profits } \\
\text { permitting) }\end{array}$ & $\begin{array}{l}\text { Maximum } 6 \% \text { of } \\
\text { nominal value } \\
\text { of shares as the } \\
\text { first dividend } \\
\text { A second } \\
\text { dividend, } \\
\text { calculated as } \\
50 \% \text { of the net } \\
\text { proceeds after } \\
\text { tax from the } \\
\text { portfolio of } \\
\text { assets which the } \\
\text { bank holds as } \\
\text { counterpart to } \\
\text { its total reserves }\end{array}$ & $\begin{array}{l}\text { Maximum } 12 \% \\
\text { of nominal } \\
\text { value of shares } \\
\text { as a first } \\
\text { dividend } \\
\text { A supplementary } \\
\text { second } \\
\text { dividend is } \\
\text { annually } \\
\text { determined by } \\
\text { the General } \\
\text { Council (Board) } \\
\text { of the bank } \\
\end{array}$ & $\begin{array}{l}\text { Maximum } 6 \% \\
\text { of nominal value } \\
\text { of shares as a } \\
\text { first dividend } \\
4 \% \text { of nominal } \\
\text { value of shares } \\
\text { as a second } \\
\text { dividend } \\
\text { A third } \\
\text { "supplementary" } \\
\text { dividend not } \\
\text { exceeding } 4 \% \\
\text { of the amount of } \\
\text { the reserves }\end{array}$ & $\begin{array}{l}\text { Maximum } 5 \% \\
\text { of paid-up } \\
\text { capital }\end{array}$ & $\begin{array}{l}\text { Maximum } 10 \% \\
\text { of issue value } \\
\text { of shares }\end{array}$ & $\begin{array}{l}\text { Maximum } 6 \% \\
\text { of the share } \\
\text { capital }\end{array}$ & $\begin{array}{l}\text { Maximum } 6 \% \text { of } \\
\text { nominal value } \\
\text { of shares as the } \\
\text { first dividend } \\
\text { A second } \\
\text { dividend of a } \\
\text { maximum of } 6 \% \\
\text { of the nominal } \\
\text { value of shares } \\
\text { approved } \\
\text { annually by the } \\
\text { General } \\
\text { Assembly } \\
\text { (general } \\
\text { meeting) of the } \\
\text { bank }\end{array}$ \\
\hline
\end{tabular}

* Cantonal governments, rather than central government.

** Some central banks (e.g. the South African Reserve Bank) limit the number of shares that shareholders may own. Sources: Rossouw \& Breytenbach, 2011a and used in Rossouw \& Breytenbach, 2011b; own additional research. 


\section{Conclusions}

This paper draws attention to an eclectic group of institutions about which very little has been published, namely central banks with private shareholders. A number of conclusions can be drawn from this paper.

The organisational and governance structures of central banks have received very little attention in the literature on monetary policy and central banking. More attention should be focused on this area of research, as central banks can draw on one another's experiences in this regard.

Only a small number of central banks have private shareholders, and an even smaller number (Belgium, Greece, Japan, South Africa, Switzerland and Turkey) allow shareholding by the general public. An even smaller group (Belgium, Japan, South Africa and Switzerland) allows its shares to be held by foreigners, but shareholder rights are often limited by the number of shares an individual can hold, and/or by limitations on voting rights.

The large differences in the approach of central banks with shareholders to the payment of dividends are noteworthy. Dividend policies range from a fixed dividend prescribed by law to a large degree of discretion in the payment of dividends. From an investment perspective, only the central banks of Belgium and Greece (albeit only for residents in the latter instance) can be considered. These are the only central banks where dividends are not capped or otherwise limited, but are linked to the profitability of the central bank. However, the central bank of Greece could not sustain its dividend payments after the financial crisis of 2008.

The Austrian central bank is the most recent example of nationalisation of a central bank. This nationalisation, the first in some 35 years, received surprisingly little attention and is an area for further research. Likewise, the "wave" of central bank nationalisation in 1974 and 1975 is an area for further research.

There is no single answer to the matter considered in this paper, namely whether private shareholding still has a role to play in the structures of these central banks, but a number of conclusions can be drawn. Firstly, from an investment-return perspective, only the central banks of Belgium and Greece (albeit only for residents in the latter instance) can be considered a growth investment by investors.

Secondly, in the case of Italy, the shareholding in the central bank has been used as an instrument to recapitalise ailing commercial banks. This is the only such example of emergency liquidity or solvability assistance to ailing banks, but this approach can be replicated (if needed) by the 12 Federal Reserve Banks in the US, as these institutions only have banks as shareholders, as is the case in Italy.

Thirdly, the shareholding structure of these banks contributes to improved governance in the case of the central banks of Belgium, Greece, Italy, South Africa, Switzerland and Turkey. This is not the case with the Bank of Japan and the 12 Federal Reserve Banks in the US, as these institutions do not have ordinary general meetings for shareholders where the shareholders can call the management of the central bank to account.

Lastly, a central theme that emerges from the analysis of these central banks is that their shareholders play no role in the formulation and implementation of monetary policy. Moreover, no evidence can be found that central banks with shareholders in any way outperform central banks without shareholders.

\section{Endnotes}

1 This section draws on Rossouw and Breytenbach (2011a).

2 Some of these institutions were initially known as banks of issue, that is, institutions entrusted by the government with the monopoly power to issue banknotes.

3 As is shown below, the Central Bank of Pakistan was subsequently nationalised.

4 Banca Monte dei Paschi Siena was founded in 1472 and is the oldest bank in the world.

5 This is an interesting way of providing emergency liquidity assistance (also known as lender-of-last resort assistance) for troubled banks. 


\section{Acknowledgements}

The author wishes to acknowledge Economic Research South Africa (ERSA) for financial assistance with this paper.

\section{References}

ANNUAL REPORTS of the central banks of Austria, Belgium, Greece, Italy, Japan, South Africa Switzerland and Turkey (various copies of different years).

ARCHER, D. \& MOSER-BOEHM, P. 2013. Central bank finances. BIS Papers No 71. Basel: Bank for International Settlements.

DE KOCK, M.H. 1939. Central banking. London: P S King \& Son.

DE KOCK, M.H. 1956. Central banking. ( $3^{\text {rd }}$ ed.) London: Staples Press.

DE KOCK, M.H. 1974. Central banking. (4 ${ }^{\text {th }}$ ed.) London: Staples Press.

DISCUSSIONS with Mr Gerhard Hohäuser of the Austrian National Bank.

DISCUSSIONS with Mr Paul Moser-Boehm of the Bank for International Settlements.

EN PUBLISHING. [S.a.] Available at: http://www.enpublishing.co.uk [accessed February 2014].

INVESTOR ACTIVE. 2014. Italy parliament approves revaluation of central bank's capital. Available at: http://www.iii.co.uk/news-opinion/reuters [accessed February 2014].

LYBEK, T. \& MORRIS, J. 2004. Central bank governance: A survey of boards and management. IMF Working Paper WP/04/226. Washington: International Monetary Fund.

MEIRING, J.G. 1994. Biographical sketches of directors. Pretoria: SA Reserve Bank.

NATIONAL BANK OF BELGIUM. 2009. Corporate report 2009. Available at:

http://www.nbb.be/pub/01_00_00_00_00/01_00_00_00_00.htm?1=en [accessed February 2014].

OESTERREICHISCHE NATIONALBANK. 2009. Annual report. Vienna: Oesterreichische Nationalbank.

RESERVE BANK OF NEW ZEALAND. 2009. The history of the Reserve Bank of New Zealand.

Wellington: Reserve Bank of New Zealand.

ROSSOUW, J. 2004. A brief note on Nel and Lekalake: Monetary transparency in South Africa. South African Journal of Economics, 72(5).

ROSSOUW, J. 2010. South African Reserve Bank: History, functions and institutional structure. (2 ${ }^{\text {nd }}$ ed.) Pretoria: SA Reserve Bank.

ROSSOUW, J. \& BREYTENBACH, A. 2011a. Identifying central banks with shareholders: A review of available literature. Economic History of Developing Regions, 26 (Suppl 1).

ROSSOUW, J. \& BREYTENBACH, A. 2011b. When private shares meet public interest. Central Banking, Vol XXII:2, November.

The Federal Reserve System. 2005. Purposes \& Functions. Washington: Board of Governors of the Federal Reserve System. Available at: http://www.federalreserve.gov/pf/pf.htm [accessed February 2014].

STATUTE of the Bank of Greece.

STATUTE of the Bank of Italy.

STATUTE of the Bank of Turkey.

STATUTE of the National Bank of Belgium.

UNITED STATES OF AMERICA. 1913. Federal Reserve Act.

WEBSITES of the central banks of Austria, Belgium, Greece, Italy, Japan, South Africa, Switzerland and Turkey. 